\title{
12 \\ Postcard from Plaguetown: SARS and the Exoticization of Toronto
}

\author{
Carolyn Strange
}

'“Bad news travels like the plague. Good news doesn't travel well"'. While this epigram might have appeared in an advertising or marketing textbook, they were the words a Canadian politician chose to explain why the federal government sponsored a Toronto rock concert in the summer of 2003. As the Senator stated, 3.5 million dollars was a small price to pay for an event held to restore confidence in a city struck by SARS. The virus - first diagnosed in Toronto in March 2003 - had already claimed 42 lives; international media coverage of the outbreak had strangled the economy. While public health officials imposed quarantine and isolation measures to combat the spread of SARS bureaucrats and business leaders were equally active, treating the virus as an economic crisis caused by negative publicity. 'SARSstock', as locals dubbed the concert, was one of many events prescribed to repair and revitalize the city's image post-SARS. By drawing close to half a million fans with big name musicians, including The Rolling Stones, it provided Canadian and US newspapers and television outlets with a splashy 'good news' item. Local media commented that the concert gave Torontonians a much-needed tonic. As the Toronto Star declared, it proved to the world that 'life and business here rock on'. ${ }^{1}$

When the World Health Organization (WHO) issued its advisory against 'unnecessary travel' to Toronto in April 2003, not only suspected SARS carriers but the city itself felt borders close around it, cutting off vital flows of traffic to the city. ${ }^{2}$ It is thus possible to frame the economic consequences of SARS within the longer history of quarantine, cordons sanitaires and their commercial dimensions (as Hooker also argues in Chapter 10). Difficult to police and frequently a flashpoint for violent protests, public health measures that restrict the movement of people and goods have typically spawned economic crises. Indeed, distress over the financial impact of disease containment, rather than concerns over prejudicial treatment of suspected carriers, have historically pushed medical authorities to relax quarantine. ${ }^{3}$ While strict maritime quarantine provisions gave way over the nineteenth century to individual medical inspection, a governing strategy 
that focused on monitoring individual movement, quarantine continued to clash with commerce in the twentieth century, as Nayan Shah and others have shown. ${ }^{4}$

In Toronto, however, the SARS-induced economic crisis sprang primarily from a mediatized culture of fear and externally-imposed travel advisories, rather than from locally-imposed quarantine regimes. Alarming news stories about the virus's transmission and deadliness chilled tourism, Toronto's second-largest industry (after banking and finance), and a sector largely dependent on image. ${ }^{5}$ In the midst of the crisis (at which point 16 people had already died) Toronto Mayor Mel Lastman announced that the city's publicity problem overshadowed its health emergency: 'it's not the disease that's doing the damage - it[']s public perception about SARS that's hurting Toronto's tourism industry'. ${ }^{6}$ This statement announced the city's commitment to find ways to reinvent its identity - a campaign that would prove as daunting as the effort to combat the virus.

How did SARS recast Toronto in the eyes of the world, and how was its image refashioned into one that signaled the renewed vitality of life and business? This post-modern public health crisis unfolded in ways that took Torontonians by surprise. First, while local health bodies ordered individuals into isolation it was not city, provincial or federal authorities that imposed travel restrictions but the supra-national WHO. Twenty-six countries followed suit with their own travel warnings, while many businesses and professional associations advised their employees and members to cancel Toronto trips (or in many cases, any travel to Canada). This, then, was a moment when a global body undermined the nation-state's capacity to regulate its own borders in the interest of commerce. Second, international media coverage of SARS transformed Toronto into a latter-day plaguetown, an economically vibrant modern city cut to its knees by a mystery bug. ${ }^{7}$ Not only was Toronto sick, but newsmakers identified SARS as an exotic virus, transported by an Asian person from Hong Kong. The new definition of Toronto as 'the only place outside of Asia' to be placed on the WHO's travel advisory list was more than a statement of fact; repeated endlessly the phrase became a trope that merged Toronto with Asia, on the one hand, and underlined its anomalous inclusion, on the other. These multiple processes of identification textually exoticized Toronto, by tying it authoritatively (confirmed once epidemiologists traced SARS to southern China) to the 'East'. Knocked off its secure Western perch, the North American city fell into the imagined geography of dangerous disease, unexpectedly transmuted into an object of curiosity and fearful scrutiny.

Recovering from SARS, particularly through state-sponsored tourism promotion, such as the SARSstock concert, involved far more than proclaiming that the virus had been conquered; rather, as I argue, these efforts exposed, confronted and courted ambivalent sentiments about race in an officially 
multicultural city. Promotional schemes worked through a variety of media to recast the city as safe and as safely Western. Official strategies designed to address Toronto's 'publicity problem', including promotional songs, entertainment packages, postcards, television commercials, websites, and magazine advertisements, worked initially to de-exoticize the city, by inducing Torontonians to become 'tourists in their own town'. The second phase looked outward and drew on Toronto's pre-existing identity as an ethnically and culturally diverse city, with colorful and consumable ethnic enclaves. ${ }^{8}$ Once SARS seemed defeated, tourism marketers gave the city's exoticism a romantic and commercially appealing gloss, free of dangerous associations.

\section{Toronto, exotic plaguetown}

SARS constituted a medical crisis but it also sparked a historically-coded and racially-loaded struggle over representation. Multimedia representations of the SARS outbreak in Toronto incorporated the city within the code of medieval plague. In March 2003 SARS the virus began to attack human bodies; at the same time SARS, the new brand name for 'mysterious deadly infectious disease', marked Toronto as plaguetown. 'SARS' signified the new millennium version of plague, in which an exotic disease 'invades' a modern city, thrusting its citizens into what one journalist called a 'new medievalism' of quarantine and fear. ${ }^{9}$ Toronto's perplexing outbreak connected historical narratives to new doomsday imaginings of wealthy, modern cities' vulnerability to military and microbial threats. ${ }^{10}$ Likened to the 9-11 attacks and the anthrax scare of 2001, the event inspired North American and European journalists to ponder: 'if it could happen in Toronto, was anywhere [in the affluent West, by implication] safe?'11 While representations of SARS pitched Toronto into the past and linked it to the new threat of anti-Western terrorism, they also wrenched the city from its geographical moorings and seemingly secure Western identity. News reports of the disease's origins as a virus that had jumped from 'exotic' animals to humans in Guangzhou invoked Western cultural scripts of the mysterious and dangerous Far East. ${ }^{12}$

Analyzing the touristic and marketing aspects of SARS' impact on Toronto does not diminish the seriousness of the disease, which claimed a total of 44 lives. Aside from those who died, hundreds of people became seriously ill, and many have failed to recover fully. ${ }^{13}$ Torontonians in isolation faced financial and personal hardship, while thousands of hotel and restaurant workers were laid off, many permanently. Thus images of Toronto - the sick city, its normally bustling streets eerily deserted - were hardly fictional. But the material effects of news discourse were powerful and pervasive; mass media narratives of Toronto as a city that had caught an exotic disease racialized SARS and authorized what Asian people defined as racial profiling. ${ }^{14}$ 
As Peter Mason argues, studying the exotic is to take as a subject of inquiry 'a representational effect, produced and reproduced', rather than a quality fixed in any geographic, ethnic or ontological sense. ${ }^{15}$ While the exotic has historically referred to the non-Western 'other', conceptions of difference also surface in dominant constructions of familiar people or places, which appear strange or illogical. Thus when international public health experts, along with Western media outlets represented Toronto as a North American place that had caught an 'Asian' disease, same flipped into other, and the famously bland city became urbana incognita.

Several weeks prior to the diagnosis of SARS in Toronto, international health experts had traced the virus's origin to China. Already associated with mysteriousness and 'inscrutibility' in Western representations of 'the Orient', China's association with this new health threat reinforced historic Eurocentric readings of the Chinese as diseased and dangerous. ${ }^{16}$ While travel promoters in non-Western parts of the world (and Asia and Africa in particular) still manipulate Western scripts of exoticism for profit, negative judgments bloom at the first sign of bad news, as they did when Western news outlets first reported that atypical pneumonia had emerged in southern China. Following the WHO's accusations that the Chinese government had been uncooperative and secretive, Western television and print media repeatedly broadcast images of Chinese sanitation workers scouring wild animal markets, wiping countertops with disinfectant, and posting 'no spitting' signs on lamp posts. And when the WHO issued its first-ever travel advisory on 2 April, recommending against nonessential trips to Hong Kong and Guandong Province, Western governments and news outlets readily accepted the judgment that East Asia ought to be avoided.

The WHO's second travel advisory was another matter. Its warning against non-essential trips to Beijing, Shanxi Province and Toronto performed a double function: on the one hand, Toronto was now officially one of the world's 'hot zones' of disease; on the other, the announcement erased the city's imagined and projected identity as a safe, North American city. WHO travel alerts in April and May, which referred exclusively to Asian destinations (Taiwan, Singapore, the Philippines, and further Chinese provinces) reconfirmed the city's newly exotic identity. Consequently Toronto, 'the only location outside of Asia' to have warranted a travel advisory, became strange within the West. Historic plague and leprosy references (as in, 'Toronto is limping toward "leper status"') were also racially coded and loaded ('Basically Toronto is taboo') ${ }^{17}$ in print and in television news lead-ins. On the day when the WHO issued its advisory, for example, the Toronto Globe and Mail's front page read: 'SARS creates a city of pariahs. Shunned by Canada and the US alike, residents increasingly feel like lepers'. The story went on to add that 'US newspapers have nicknamed [Toronto] Pariah City'. These signifying practices, which deployed a non- 
English term (pariah) for stigmatized, turned Toronto into a loathsome and dangerously exotic locale - a city, like lepers, that deserved to be shunned.

The scope and deadliness of SARS in Toronto, and doubts about the capacity of government and medical agencies to cope reinforced the city's image as a backward place, not quite up to modern standards of hygiene and scientific rationality. When SARS first appeared in Toronto in the spring of 2003, the virus' spread seemed incomprehensible, considering the city's wealth of medical facilities and expertise. ${ }^{18}$ But when Toronto's hospitals turned out to be disease vectors rather than places of cure, and when its public health officials squabbled publicly, disseminating conflicting information about transmission and symptoms, Toronto's North American know-how lost all credibility. Even more embarrassing to Canadian health ministries was the fact that comparatively poor and under-resourced Asian countries, most notably Vietnam, managed to contain SARS more quickly and effectively. ${ }^{19}$ The rapid spread of SARS in Toronto, and its reappearance several weeks after health officials officially declared the outbreak over left the city in company with the world's worst-hit locations - Guangzhou, Beijing and Hong Kong. Exoticized representations of Toronto thus drew upon and reinforced the lethal failures of its public health system.

If this is how Toronto appeared to the world, Canadian media coverage of SARS, in contrast, defined the virus as an exotic invasion. Without expressly accusing Chinese immigrants of transporting SARS news stories played on historic anti-Asian and anti-immigrant attitudes. In latenineteenth-century Canada, as in many other countries where Chinese people had immigrated or sojourned as workers, immigration restrictions were implemented in the form of racially-specific head taxes. In 1923 the federal government passed the Chinese Immigration Act, more commonly known as the Chinese Exclusion Act, which all but prevented immigration of Chinese nationals, between 1923 and 1947. After this Act's repeal, and the institution of an official policy of multiculturalism in the 1970s, immigration from China and other parts of Asia increased substantially, comprising a key component of the Canadian 'mosaic' ${ }^{20} \mathrm{But}$ shifting immigration patterns and multicultural flag-waving failed to erode deeply ingrained cultures of racism and xenophobia, which have reasserted themselves in moments of national anxiety. For example, in 1999 news accounts of illegal arrivals from China speculated before they had even arrived that they might be criminals (why had they not applied to immigrate legally?) and disease-carriers (they probably had AIDS); in both respects these Chinese were national security threats. ${ }^{21}$ As the Chinese Canadian National Council protested, the SARS crisis in 2003 did not invent associations between the Chinese, disease and danger in the minds of Euro-Canadians; rather it ignited an existing store of antiimmigrant and anti-Chinese policy and sentiment in Canada generally and Toronto specifically. ${ }^{22}$ 
Content analysis of mainstream print media coverage of SARS confirms that Canadian readers were cued to read the virus as an Asian plague. Images, headlines and text tied mystery, danger and foreignness. In the Toronto Globe and Mail, for example, 44 per cent of its stories on SARS, between April and June 2003 included images of Asian people, particularly Asians wearing masks. ${ }^{23}$ The racialization of SARS was anchored through the public identification of Canada's first SARS victim, a Toronto resident, who had caught the virus while staying at Hong Kong's Hotel Metropole. Local papers named the woman, revealed where she lived, and provided her immigrant status (she was a landed immigrant who had only recently moved from Hong Kong). Thus, not only did SARS not 'belong' to Canada but neither did Toronto's case zero. ${ }^{24}$ Suspicions that all Chinese people, irrespective of immigrant status or travel habits, were disease carriers led Torontonians to boycott businesses in the city's downtown and satellite Chinatowns. When Asian people called the Toronto Public Health agency's SARS hotline they frequently complained that they had been victims of 'racial profiling'. In her report on the city's efforts to combat SARS, the Chief Medical Officer of Health confirmed their allegations:

certain groups were particularly burdened by the pressures of intense public attention. The Chinese and East Asian communities were associated with the geographical origin of the outbreak and other 'hotspot' locations where SARS was present. ${ }^{25}$

Accounts of Toronto's vulnerability to a non-native virus thus interpolated biological narratives of invasion and cultural narratives of racial contagion. These constructions conformed to Western discourses of the 'Far East' while displaying specifically Canadian strains of Sinophobia. Unlike the Chinese immigrants who had historically been excluded from Canada, or the boat people who had been deported, Canadians recognized that this foreign disease could not be shut out. As one journalist darkly observed, 'an exotic animal market in Guandong Province is only hours away' ${ }^{26}$

A deep sense of misidentification, and not simply concern about Toronto's economy, provoked Canadian health officials and politicians to express 'bewilderment and anger' over Toronto's inclusion on the WHO's travel advisory list. One Canadian policy analyst expressed his disgust, by complaining that the WHO's announcement 'ha[d] soiled this city's signature reputation for hygiene'. ${ }^{27}$ The city's Chief Medical Officer of Health flatly rejected Toronto's linkage with Asia and its SARS crisis: 'To categorize us as close to Beijing or other parts of China I think is a gross misrepresentation of the facts'. Toronto microbiologist Donald Low, a leading authority on the nature of SARS and its containment, was far less diplomatic: 'It's a bunch of bullshit!' In a cooler moment Dr. Low alleged that the WHO's announcement was based on 'politics', not science: 'I think they're looking 
for another scapegoat. And I think we're the scapegoat'.$^{28}$ By distinguishing politics from microbiological 'evidence' he hinted that the WHO had chosen Toronto in order to add a token Western location to its list of Asian SARS 'hotspots'. The Times of London agreed: 'The situation [in Toronto] is not at all the same as in Beijing... it was included for reasons of political correctness, to balance the advice on China' ${ }^{29}$ In an unguarded moment, the Province's commissioner of public health protested, 'We're not some rinky-dink Third-World country'. After all, Toronto's 'public health infrastructure' must necessarily be superior to any in Asia. ${ }^{30}$ The most explicit charge of anti-Western global health politics appeared in Canada's rightwing National Post, in which an editorialist demanded: 'Why did the WHO strike at Toronto? Was it a case of national ethnic profiling - wanting to lift the burden off China and Asia and drop it into the lap of a whitish North America?'31

These shrill responses to Toronto's undesirable exoticization invoked the myth that Canada is a white, technologically advanced and safe nation. But swearing, accusing the WHO of politicking scientific incompetence, as well as accusing the WHO of anti-'whitish' racism failed spectacularly to reassure the world that Toronto had SARS under control. The city's public relations nadir occurred when Mayor Mel Lastman appeared on CNN's Larry King Live program immediately after the advisory was announced. The leader of North America's fifth largest city, Lastman squandered an opportunity to articulate reasoned objections to the WHO's decision and to advise millions of US and Canadian viewers that Toronto remained a familiar, safe city for visitors and residents. Instead he responded with an apoplectic display of arrogance and ignorance about the WHO:

They don't know what they're talking about. I don't know who this group is, I [sic] never heard of them before. I'd never seen them before. Who did they talk to? They've never even been to Toronto. They're located somewhere in Geneva. ${ }^{32}$

Relying on his trademark folksy style, the mayor provided millions of viewers with reason to believe that the WHO's assessment of Toronto was sound.

\section{Managing the exotic}

From a more considered position than the one he took in his disastrous CNN interview, Mayor Mel Lastman struck a SARS Advisory Task Force and gave it the mandate to re-brand Toronto. Business leaders and civic boosters fought back by peddling promotional packages for tourists; just as significant were their strategies to 're-brand' the city. Refashioning Toronto's image became an economic and political priority, involving all 
three levels of government as well as task forces, businesses and community groups. Unlike colonial Capetown or Bengal, where imperial governance found expression in overtly racial strategies of rule, or early twentieth-century San Francisco, where health officials could impose racespecific restrictions on movement in the name of public health, the association of SARS with Toronto's Asian communities in 2003 had no official authorization. In fact, officially-orchestrated image recovery would depend on the selective deployment of Toronto's pre-SARS identity as an ethnically diverse city, with one of North America's largest and most visible Asian communities. How, then, to maintain the touristic appeal of ethnic exoticism while undoing powerful, historically-rooted associations between Asians and disease? This was the challenge that politicians, bureaucrats, and marketing consultants confronted. The unwanted branding of Toronto as plaguetown, and its subsequent re-branding post-SARS is thus an opportunity to analyze the discursive relationship between illness and the exotic beyond historians' temporal and geographic focus on colonial contexts and colonized peoples.

Western representations of the exotic have never been wholly negative, of course. ${ }^{33}$ Imperial adventure writing on Asia and Africa depicts intriguing, enlivening destinations and contemporary commercial and governmental travel promotion continues to bank on these historic associations. Places historically exoticized in colonial literature reappear two or three centuries later in glossy brochures as appealingly out of the ordinary for Western tourists. Consider, for example, Exotic destinations for wheelchair travelers: hotel guide to the Orient: Hong Kong, Macau, Singapore, Taiwan, Thailand. ${ }^{34}$ Here we see a typical sign linkage - exotic-Orient - with specific countries beaded along a pan-Oriental string. The WHO's travel advisory list was almost identical, save for the geographically and culturally jarring, faintly absurd addition of 'Toronto'. ${ }^{35}$

In Asian and other non-Western countries, private businesses and tourism agencies manipulate colonialist representations of their exoticism in order to gain a market edge over Western destinations. 'Marketing the margins' has become a standard element of cultural self-fashioning in tourist promotion, as well as in post-colonial literature and art. ${ }^{36}$ An example of commercially motivated practices of self-exoticization appears on the Tanzanian government's official website, which invites the visitor to 'Rediscover the wild, romantic Africa of your dreams'. Needless to say, the hailed 'you' is not the Tanzanian citizen but the wealthy adventurer in search of the exotic, even if accessed only through a web portal. ${ }^{37}$ Tourism Toronto's 'World within a city' campaign, launched after the SARS crisis subsided, would follow the same strategy, carefully avoiding any mention of an 'Asian' disease while vigorously promoting the city's 'authentic' Chinatowns.

The image of a mysterious plague raging through a city run by incompetent politicians and defensive medical authorities drew world-wide media 
coverage but it was hardly the publicity that local business leaders would have wished for. Well before the initial outbreak of SARS, programs had been tabled to freshen Toronto's image and revive its sagging tourist industry. In 2000, for example, the municipal government adopted a resolution to 'position Toronto by telling ourselves and the world what a really great City Toronto is'. Two years later the Commissioner for Economic Development, Culture and Tourism had presented an elaborate plan for the development and marketing of a comprehensive "brand" strategy' for the city, one designed to replace its 'unfocused and unexciting' image - clean and safe, and not much else. ${ }^{38}$ A coalition of civic leaders, named the Toronto City Summit Alliance, had reached a similar conclusion, asserting that 'stronger promotion of the Toronto region as a visitor destination' required well-funded marketing. ${ }^{39}$ Ironically it took SARS and the subsequent public relations debacle to push all three levels of government to pump money into promotions designed to 'raise Toronto's international profile' on the city's own terms: to combat fear, to inspire pride, and to entice tourists and investors. While medical workers tackled the virus in the spring of 2003, advertising and marketing firms turned to the parallel task of remaking Toronto's image.

\section{The redomesticated city}

Tourism advisors faced a daunting and unfamiliar challenge: how could a city, previously renowned for its safety and cleanliness, regain firm financial footing if its own citizens, let alone foreign travelers and investors, feared walking the streets, riding the subway, attending work or school? While risk is a prominent concern in the international tourism industry, ${ }^{40}$ it has never been a key issue for Canadian tourism marketers and officials, other than those who deal with the dangers of avalanches or bears. In tourist Canada, risk is remote, while cities are generally considered secure for visitors. Toronto's tourism industry has traditionally rested on its reputation for visitor security, certainly in contrast to neighboring US cities, where reports of citizens and tourists victimized in drive-by shootings, muggings and carjackings are frequent. In the Toronto tourism commissioner's 2002 report on Toronto's most marketable features, for example, 'safest large metropolitan area in North America', and 'comprehensive health care' were noted as key attributes of 'Toronto the Good'. ${ }^{41}$ Before SARS, Americans were more likely to associate Toronto and Canada with bland civility, rather than riskiness. For instance, a 2002 database search of US news stories on 'danger' produced 75 hits for Toronto, compared to 690 for Los Angeles and 480 for Chicago. One US journalist who covered the SARS outbreak commented sarcastically on the absurdity of Toronto's new reputation for riskiness: 'The SARS epidemic requires American newspaper readers to adjust to the novelty of seeing the words 'danger' and Toronto in the same sentence... Canada is a famous 
underperformer for the creation of interesting news' ${ }^{42}$ As it happened, US travelers adjusted rather quickly to the news that Toronto had become risky. By the end of April 2003, 14 per cent of American air travelers declared that they had canceled trips to the city out of fear, and big-name American movie stars, performers, and sports figures withdrew from scheduled Toronto appearances.

SARS-struck Toronto suddenly appeared on the international mediascape in the way that exotic locales typically appear in Western newscasts: as a dangerous, mismanaged place. While some local politicians spoke gloomily about the economic costs others considered how the international publicity machine might be harnessed to revive the tourist industry. As prominent City Councillor Olivia Chow reflected, 'we didn't want this kind of publicity but now that we have the world's attention we might as well use it to send a different message about our city'. ${ }^{43}$ Medical officials' daily briefings about Canadian public health measures and favorable assessments from the US Center for Disease Control concerning the outbreak's management were inadequate; they provided scientific information rather than reassuring images. Messages capable of swaying locals and potential visitors required different messengers, messages, and media, City Council decided.

In response the SARS Advisory Task Force's initiatives, and other recovery efforts conducted during and shortly after the initial SARS outbreak focused initially on redomesticating the city. Clustered around the concept of 'belonging', events and promotions encouraged locals to re-embrace their own city. A campaign of strategic exoticization emerged only after the city seemed to be securely SARS-free. Reminiscent of Toronto's pre-existing slogan, 'Diversity our Strength', post-SARS promotional campaigns emerged under the trademarked logo, 'Toronto: the World Within a City' - a place rich in consumable culture while also 'safe and secure'.

\section{Belonging in Toronto}

Official SARS recovery efforts initially turned against Toronto's worldly qualities in an effort to de-exoticize Toronto's image. As a non-native disease introduced by a non-native, SARS did not belong in Toronto and it did not belong to Toronto; yet there were millions of Torontonians who did belong, but who feared mixing in public, especially in the city's Chinese business districts. Recognizing that attracting foreign visitors was unlikely while travel advisories were in effect, the first tourism promotion campaigns targeted city residents with money to spend and a desire to help prop up the economy. In launching his Task Force, the Mayor reminded his fellow citizens (or the civic-minded man, at least) that economic regeneration began at home:

there are 2.5 million people in this city who have one heck of a lot of economic clout. Let's put it to use. Treat your wife or your girlfriend to 
dinner out. Stay in a hotel for the weekend. Go and see a show or cheer on the Jays. ${ }^{44}$

Thus, even before medical efforts to eradicate SARS had succeeded, local government and business leaders urged Torontonians to prove that the city was 'safe to live in and to visit', as long as one avoided hospitals. Most importantly, if more residents walked the streets and crowded into restaurants and sporting events foreign journalists might be prompted to forget Toronto's plaguetown identity.

Fueled by a 5 million-dollar budget, an aggressive, multi-pronged marketing campaign to refamiliarize the city began the day after the WHO announcement. Treating the city as a product and its citizens as the prime market, revival tactics turned Torontonians into tourists. Mayor Lastman initiated rebranding efforts under the banner of 'Toronto You Belong Here'. At a press conference geared toward Mother's Day celebrations, the Mayor decoded the catchphrase: 'this simple slogan shows that Torontonians are the warmest, most welcoming people on earth'. The logo conveyed similar sentiments, though in an understated way: the word 'Toronto' appeared in a plain, lower-case font, with 'you belong here' added underneath, in hand writing that evokes the look of a homely note. ${ }^{45}$ Advertising firm BBDO Canada Inc. devised the slogan and also assembled a series of print, radio and television advertisements in local media 'to engage Torontonians to enjoy their City'.

Performing one's civic duty by behaving like a tourist is a task far less onerous than adhering to a public health officer's quarantine order, but BBDO and city tourism leaders recognized that fearful residents needed prodding. If Torontonians missed press conferences and advertisements, then they might meet a team of 'young and energetic uniformed ambassadors', who were posted at the main train station and shopping malls. One of the ambassadors' tasks was to distribute 'Toronto: You Belong Here' packages, which included information about city features along with coupons relating to local 'signature' events, such as fireworks displays. Another of their jobs was to greet passengers at the airport, in conjunction with Air Canada's 'Canada Loves Toronto' campaign. When traveling their ambassadorial beats they drove SUV's 'branded with the "Toronto: You Belong Here" slogan'. This un-Canadian orgy of self-love and selfpromotion was more than an attempt to compensate for the drop in tourist arrivals: at a deeper level the belonging campaign reassured Torontonians that they need not feel like 'lepers' or 'pariahs' on the global health stage. This was not plaguetown: it was our town. ${ }^{46}$

If New York and San Francisco had signature songs, then why not Toronto? BBDO commissioned 'The Toronto Song' to induce civic pride and to reacquaint Torontonians with their home town. The winning entry, 'Right Here with $\mathrm{Me}^{\prime}$, played on local radio stations and provided the audio 
background for 30 and 60-second commercials, which advertised local festivals and attractions, such as the 'Celebrate Toronto Street Festival' and the Molson Indy car race. A folk-rock tune, performed by Jason Gleed, (a local composer and songwriter) accompanied lyrics about separation and joyful reunion ('cause you belong right here with me', the chorus calls out boisterously). But the song's bridge, introduced with a minor chord and sung at half tempo, expresses the singer's gloominess over abandonment:

You've gone and done it again
You forgot where you came from
But you can't erase your home
Cause when you run away
You're only running from yourself
You don't need anyone else -
Except me

In the voice of a jilted lover, hurt but confident that his amour will return, the singer expresses the feelings of a city troubled that its own citizens turned their backs on their home town. But after the song's dark bridge, its up-beat, anthem-like chorus powers toward a future of togetherness. As the advertising firm explained, the song and the commercial were selected to 'captur[e] the emotional bond of Torontonians to their city'.

The Toronto Song was not commercially released but it was posted as a downloadable MP3 file on the official City of Toronto website. All of the 'you belong' promotional material and commercials directed visitors to the site, which provided a regularly updated events calendar as well as coupons for local attractions. Another downloadable feature available in mid-2003 was a virtual postcard. By clicking the 'Create your own City of Toronto postcard!' link, a generic postcard template popped up. Unlike the news photos of decimated Chinatown thoroughfares and empty malls that continued to circulate in 2003, the recovery campaign's image of Toronto presented the downtown Toronto skyline from a distance, with the 'you belong' logo on the bottom left. The vantage point is the shore of the Toronto Islands, and the point of view aligns with that of a lone cyclist, pausing to take in the view on a warm day. A sailboat skips by and the city's most recognizable buildings, the CN Tower and the SkyDome stadium, both major tourist attractions, balance financial towers and hotels. On the right sidebar, two city scenes (a fashionable café patio and the streetscape of the city's main theater strip) along with an image of spectators filling the SkyDome accompany a close-up of a cuddly-looking polar bear cub. Yet another bear, a grizzly, adorns the virtual 8-cent stamp. Although neither type of bear lives anywhere near Toronto (save those on display at the Metro Toronto Zoo), they are recognizably Canadian totems that represent the entire country as a barely-tamed wilderness. In concert 
with the Toronto Island view, the animals distance the viewer from the urbanity of Canada's biggest city, where a mystery disease was still claiming lives. The postcard slogan, again in a memo-style handwriting font, further connotes tentativeness toward the city in the phrase: 'It's time for a little T.O' (the already-established nickname for Toronto). Senders could not rearrange or alter the images but the site offered content options from the 'Select your Postcard's message!' link:

Having a wonderful time.

Wish you were here!

Toronto is the best!

In announcing the launch of the postcard on 17 July, Mayor Lastman declared, 'I want this postcard on bulletin boards from Paris to Beijing. Come on, Toronto, let's show the world how much we love our city'. ${ }^{47}$ In spite of its generous sprinkling of exclamation marks, however, the card conveyed ambivalence and reluctance to embrace a city still smarting from SARS: the 'you belong here' logo appeared snugly on the island side of Toronto's harbor, and only a 'little T.O.' was recommended.

\section{Toronto: World City}

Once quarantine and isolation measures appeared to end the transmission of SARS less apologetic campaigns, directed particularly to US tourists emerged. Harkening back to the City Tourism Commissioner's 2002 report, which had identified 'Toronto the Diverse' as a potential brand, this Tourism Toronto initiative emphasized the city's cosmopolitan character. Just as post-independence African nations and post-colonial creative artists market the margins by catering to Western tastes, so this campaign to restore Toronto's image as a safe and appealing destination strategically exoticized the city, symbolized through its new slogan, 'Toronto - the World in a City'. After having been marked in racial terms as a 'pariah' and designated out-of-bounds for business and leisure travelers, Toronto was repackaged (by the Provincial tourism ministry, the city, and the Toront03 Alliance, the new civic organization, which helped to organize 'SARSstock') as a place where the exotic resided in 'ethnic' restaurants and enclaves, not hospital wards.

The SARSstock mega concert on 31 July 2003 was a one-day spectacle that demonstrated the new boldness in recovery initiatives. Small-scale entrepreneurs (who had sold surgical masks by city roadsides 3 months earlier) switched to selling souvenir 'I survived SARS' and 'SARS-stock' t-shirts at the concert. Half a million spectators, as the Toronto Star put it, were 'carriers of good news'; that so many people had mingled without fearing SARS confirmed that 'the city has survived'. Headliners, such as the 
Rolling Stones, Justin Timberlake and AC/DC drew world media interest, spinning 'positive stories' in 564 North American newspapers and on several US television networks. Rather than beleaguered white-coated doctors spouting SARS transmission theories and lashing out at the WHO, the city acquired splashier spokespeople. Strutting out on stage in a fuchsia morning coat, Mick Jagger screamed: 'Toronto is back, and it's booming'. Whipping up the crowd, he added: 'This is the biggest party in Toronto's history, right? You're here. We're here'. ${ }^{48}$ Likely unaware that his words echoed the 'you belong here' recovery slogan and the 'Right here with me' song, Jagger made the sentiment sexy by embracing the city enthusiastically as an entertainment mecca. ${ }^{49}$

Aside from the concert, the recovery campaign continued to focus on refamiliarization, and reassurances that the city was safe, even if 44 of its citizens had died. In the summer and early fall of 2003, politicians and business leaders became convinced that aggressive marketing was necessary. The product was there, in the opinion of Toronto's first openly gay City Councilor, Kyle Rae. Having just hosted guests in town for the city's Lesbian and Gay Pride festival he noted that their impression of the city was

one of shock and amazement that Toronto, even after SARS, has a clean healthy downtown, lots of destinations, places to go, nightlife, art galleries, museums, great shopping. We've got everything people are looking for...It's just that we're not marketing it properly.

The president of Molson Inc., the brewery that was the primary private sponsor of the concert agreed: 'We've taken the first step in regaining our image...We've got to keep selling ourselves'.

The second major campaign, sponsored by the Province and Tourism Toronto came with a new, trademarked slogan, 'the world within a city'. The major coordinating component of this drive was and remains the Toronto Convention and Visitors' Bureau website, which incorporated the content and design of a website first designed by the Toront03 Alliance. 'Welcome to the World's Best-Kept Travel Secret', announces the 'Destination Toronto', homepage. Site visitors discover different elements of the secret, one of which is that Toronto is home to 'more than 80 cultures from around the globe'. It also offers 'international' cultural festivals, shopping with 'international flair', and 'vibrant features representing every part of the globe'. Thus, far from cringing at its status as a metropolitan crossroads, in which outsiders might at any moment introduce exotic diseases, the site extols Toronto's connectedness to the world. The 'Personality' page, which deconstructs the city's new slogan, explains precisely how Toronto embraces, but does not absorb diverse cultures:

The world within a city ${ }^{T M}$ doesn't just refer to the wealth of dining, shopping and theatre experiences Toronto has to offer...Toronto is known as one of the most culturally diverse cities in the world, and we take pride 
in the knowledge that we do not have to be homogenous to have a peaceful, thriving city.

Moving sharply from the brink of overt anti-Chinese racism, the second phase of the tourism recovery strategy turned to a cherished Canadian myth, that Canada is a tolerant, multicultural country, happily free from race wars and ethnic and religious clashes - and, by implication, free from exotic diseases as well. Unlike the 'You Belong' website, which initially included a link to a separate SARSTORONTO.COM information site, the World Within a City site yields no hits if one searches for 'SARS'.

The worldly campaign engages with the exotic strategically, in an effort to lure tourists and business travelers looking for something interesting but predictable. It invokes the colorful and unusual in romantic, nonthreatening terms. References to its 'vibrant and quirky neighborhoods' are codes for ethnic and sexual diversity: 'some [neighborhoods] can be described as "ethnic", while others reflect a particular lifestyle, business, or leisure activity' (what follows is a list: 'Greek town, Little Italy, Chinatown or the Gay Village'). While the visitor might encounter 'delightful secrets at every turn', there is nothing inscrutable about the place, no nasty surprises to encounter when 'neighborhood hopping'. In fact hosting 80 cultures does not make Toronto 'foreign' because of the city's 'amazing ability to adapt and flourish, while remaining essentially 'Canadian' - gracious, broadminded, safe and friendly'. The subtext here is safer and friendlier and more tolerant than the US, and thus a haven for US visitors. For example the 'fact file' page addresses Americans explicitly by mentioning that Toronto is located on the same latitude as northern California: '(remember that the next time it snows in California.)'

According to the World within a City site, Toronto not only has a large Asian population; more intriguingly, the Chinese comprise 'one of the largest and most visible ethnic communities'. Like the local press, which had focused on the first SARS patient's links to Hong Kong, the 'Chinatown' page notes that 'many of the city's Chinese residents are relatively new immigrants from Hong Kong'. In this recovery context, however, the commercially-active Chinese bring an approved and non-threatening exoticism to the city, and any resemblance to China is now a plus, as we see in this description of Chinatown's main intersection: 'It has grown into a frenzied, boisterous neighborhood that can easily be mistaken for Hong Kong'. Even though many medical experts agreed that the transference of the virus from exotic animals to humans in Guangzhou markets had allowed SARS to emerge, the World within a City site extols Chinatown's authentic market atmosphere:

on weekends - especially, the sidewalks are crammed with open-air food stalls, vendors and thousands of people from all backgrounds eager to shop, eat and socialize. 
Chinatown's food is equally authentic, offering 'exotic fare' and a wide selection of teas, 'some unusual to Western tastes'. Thus, even this latest and expensively produced campaign to re-brand Toronto draws on centuries-old notions of exoticism, with the Chinese the chief representatives of 'the unusual'. But equally notable is the lack of tentativeness about the 'vibrant' city. Six months after SARS hit, city tourism promoters determined that it was time for a lot of T.O., and a lot more confidence that the city could wrap the exotic safely and securely, Canadian-style.

\section{Conclusion: Toronto, a remarkable brand}

Critical studies of public health emphasize that marginalized populations the poor, the poorly-housed, the indigenous, and stigmatized ethnic groups - have historically borne the greatest burdens of medical policing. ${ }^{50}$ And in North America, the Chinese have often been singled out for discriminatory treatment, consistent, as Shah notes, 'with the logic of public health measures that routinely conflated deadly disease with Chinese race and residence'. ${ }^{51}$ The outbreak of SARS in Toronto in 2003 replayed these historic themes: a baffling virus, a suspected Asian source, restrictive quarantine. But in this instance media narratives and images (compounded by confused pronouncements from medical and civic authorities), rather than officially-imposed and discriminatory measures, gave Toronto's SARS identity as plaguetown a racial cast. Once medical officials announced that SARS had emerged, Toronto acquired an unprecedented 'publicity problem'. In a matter of days the city underwent a discursive transformation from a technologically-advanced North American city into a dangerous place. Images of empty streets and abandoned malls confirmed that a climate of fear reigned: residents were hiding, visitors beware. Alarmist coverage of the city's viral status unhinged Toronto - a city Peter Ustinov once nicknamed 'New York run by the Swiss' - from its smug, Western identity and hitched it to Asia, turning the erstwhile North American city into an object of Western curiosity.

Since Toronto's tourism industry had been in the doldrums before SARS appeared, tourism promoters saw the SARS crisis as a chance to act boldly to recast Toronto's image. ${ }^{52}$ In addition to the 'You Belong' and 'World within a City campaigns', a coalition of agencies announced in April 2004 a new project to re-brand the city. 'Re-imagining Toronto: the Quest for a Remarkable Brand', set the challenge for advertising and marketing firms. ${ }^{53}$ The winners, Brand Architecture International (along with local advertising firm TWBA/Toronto), began with a public campaign, called, 'We are Toronto'; its object was to elicit responses from Torontonians, to 'help us discover what makes Toronto different, better, special and distinct from other cities of the world'. ${ }^{54}$ The conclusion, however, was already written: ' Toronto is an amazing city and we want the world to know!'55 Evidence of racial profiling, 
harassment, job loss, and the media stigmatization of Asians in a 'whitish' city is unlikely to appear on the marketers' lists of things that people ought to know about 'diverse' Toronto. ${ }^{56}$ As the Chinese National Council's 'Yellow Peril' report cautions, analyzing recovery from public health scares solely in medical or business terms fails to expose how easily ideals of 'anti-racism and human rights' slip away. While explicit racist stereotypes have faded in Canadian public discourse, they became vivid once viral danger could be linked to an Asian source. ${ }^{57}$ Thus, whether or not brand architects acknowledge it, Toronto's exoticization and the orchestration of its image makeover cannot be understood outside of historically-rooted discourses of racial, national, and Western identities, which both constituted the mysteriousness of the virus and informed mediated strategies for the city's renaissance. 'Strong brands are built on a foundation of truth', the Toronto Branding Project declares, but in practice, half-truths will do.

\section{Notes}

1 J. Coyle, 'Exactly what we needed', editorial, Toronto Star (31 July 2003). http://www.chariotmedia.com/TorontoStar (accessed 1 July 2004). Senator Jerry Grafstein made the connection between media communication and plague transmission.

2 A. Nikiforuk, 'Fever Pitch: SARS is a reminder of the economics of disease', Canadian Business, 76, no. 10 (26 May 2003): 119-21.

3 P. Slack, 'Introduction', Epidemics and Ideas: essays on the historical perception of pestilence (Cambridge: Cambridge University Press, 1992), pp. 1-20, 12-13; M. Healy, Fictions of Disease in Early Modern England: bodies, plagues and politics (London: Palgrave, 2001); A.M. Kraut, Silent Travellers: Germs, Genes and the 'Immigrant Menace' (New York: Basic Books, 1994), pp. 24-30.

4 A. Bashford, Imperial Hygiene: a critical history of colonialism, nationalism and public health (London: Palgrave, 2004), pp. 117-18; N. Shah, Contagious Divides: Epidemics and Race in San Francisco's Chinatown (Berkeley: University of California Press, 2001), pp. 122-3.

5 The Ontario Ministry of Tourism estimated that the loss to the provincial tourism sector was two billion dollars, and that 28,000 jobs were lost. S. Thomas, 'A Year after SARS, tourists return to Toronto', 26 May 2004 (Reuters). www.reuters.com/printerFriendlyPopup.jhtml?type=topNews\&storyID=5264582 (accessed 1 July 2004).

6 Lastman mentioned this in a speech at a special meeting of City Council, 24 April 2003. www.city.toronto.on.ca/mel_lastman/speeches/sarsreponse_council_2003.htm (accessed 1 July 2004).

7 D. Gilmour, 'Coming Soon', Toronto Life, 38, no. 2 (February 2004): 60-5. Five images, each of the 1917 influenza epidemic, accompanied this story.

8 For example, 'We are home to a higher proportion of immigrants than any other city, surpassing Miami, Sydney, Los Angeles and New York'. Toronto City Summit Alliance, 'Enough Talk: An Action Plan for the Toronto Region' (April 2003): 19.

9 A representative film in this genre is 28 Days Later (2002). For a SARS-framed review of the film see E. Helmore, 'Plague upon the Brits: Not quite a SARS film, '28 Days Later' depicts viral devastation in London', New York Daily News (23 June 2003). 
10 Toronto's Chief Medical Officer of Health reflected: 'The SARS outbreak illustrated the vulnerability of Toronto to a new emerging disease and showed how vital a strong public health infrastructure is the well being of the city'. Dr. Sheela V. Basrur to Board of Health, in Toronto, City of Toronto Staff Report (9 September 2003): 13.

11 D. Gilmore, 'Coming Soon', Toronto Life, 38, no. 2 (February 2004): 60-5. The subtitle of the article reads: 'A year after SARS, here's what we've learned: 2003 was just a dress rehearsal for the inevitable pandemic', p. 60. See also 'Killer pneumonia finally arrives: we were overdue for an epidemic', Toronto Globe and Mail (18 March 2003): A17; 'Where's Rudy Giuliani when you need him? Yesterday the World Health Organization clapped the city of Toronto into quarantine. SARS became Toronto's 9/11, the worst crisis in its history'. Toronto Globe and Mail (24 April 2003): A1. These were all cited on the 'SARS headlines' page, CBC News Online website: http://www.cbc.c./news/background/sars/headlines.html (accessed 1 July 2004).

12 News reports suggested this 'exotic' link early on in the crisis, but the theory received authoritative medical endorsement in the New England Journal of Medicine. See R.P. Wenzel and M.B. Edmond, 'Managing SARS Amidst Uncertainty', New England Journal of Medicine, 348 (2003): 1947-1948. The Naylor Report reiterated the connection: 'It now appears that exotic animals in a Guandong market - perhaps civet cats or raccoon dogs - may have given the human race yet another novel infectious disease'. Learning from SARS: Renewal of Public Health in Canada. Report of the National Advisory Committee on SARS and Public Health (Ottawa: Government of Canada, 2003), p. 23.

13 Learning from SARS: The SARS Commission Interim Report: SARS and Public Health in Ontario (Toronto: Government of Ontario, 2004); For the public's health: A Plan of Action. Final Report of the Ontario Expert Panel on SARS and Infectious Disease Control. (Toronto: Ontario Ministry of Health and Long-term Care, April 2004). See also K. Donovan and T. Talaga, 'SARS: The chain of errors, Toronto Star (20 September 2003): A1.

14 C. Leung, Yellow Peril Revisited: Impact of SARS on the Chinese and Southeast Asian Canadian Communities (Toronto: The Chinese Canadian National Council, 2004), p. 2.

15 P. Mason, Infelicities: Representations of the Exotic (Baltimore: Johns Hopkins University Press, 1998), p. 1.

16 D. Manderson, "Disease, Defilement, Depravity": Towards an Aesthetic Analysis of Health' in L. Marks and M. Worboys (eds), Migrants, Minorities and Health: historical and contemporary studies (London: Routledge, 1997), p. 25. On Canada see R. Mawani, "The Island of the Unclean": Race, Colonialism, and "Chinese Leprosy" in B.C., 1891-24', Journal of Law, Social Justice and Global Development, 1 (2003): 1-21.

17 Reuters used the leper reference to describe the effects of the WHO announcement. Quoted in N. Seeman, 'Toronto Under SARS: A Media Fever', National Review Online (25 April 2003): 1. The pariah quote was prefaced with: 'Empty shops, quiet streets, hotels with high vacancy rates'. BBC News online, 24 April 2003. Cited on CBC News webpage, 'SARS in the headlines', http://www.cbc.news/background/sarsheadlines.html (accessed 1 July 2004).

18 The WHO was equally baffled by the Toronto outbreak: 'Another mystery is why the SARS virus spreads more efficiently in sophisticated hospital settings'. 'Update 93 - Toronto removed from list of areas with recent local transmission', World Health Organization, 2 July 2003. http://www.who.int/csr/don/ 
2003_07_02/en/print/html (accessed 1 July 2004). Later research confirmed that intubation, less commonly practiced in poorer countries, contributed to the rapid spread of SARS in Toronto hospitals.

19 Five days after the WHO included Toronto in its travel advisory it removed Vietnam from its lists of areas of local transmission. Vietnam had first appeared on this list, along with Toronto, parts of mainland China, Hong Kong, Taiwan, and Singapore, on 22 March 2003, and it was the first 'hot spot' officially to halt transmission. 'Update 92 - Chronology of travel recommendations, areas with local transmission', World Health Organization, 1 July 2003. http://www.who.int/csr/don/2003_07_01/en/print/html (accessed 1 July 2004).

20 In Canada, the mosaic metaphor contrasts the US metaphor of the melting pot. Multiculturalism officially values retaining ethnic and cultural distinctiveness in an immigrant nation. For a critical reading of these declared values see S.H. Razack, ed., Race, Space and the Law: Unmapping a White Settler Society (Toronto: Between the Lines, 2002).

21 Sean P. Hier and J. Greenberg, 'Constructing a Discursive Crisis: Risk Problematization and Illegal Chinese in Canada', Ethnic and Racial Studies, 25 (2002): 490-513.

22 Leung, Yellow Peril Revisited, 7. The Chinese National Council had already been engaged in efforts to force the federal government to provide redress for the Head Tax. See R. Mawani, "Cleansing the Conscience of the People": Heading Head Tax Redress through Canadian Multiculturalism', Canadian Journal of Law and Society, 19 (2004): 127-51.

23 A total of 119 SARS stories appeared in the Globe over this period. Leung, Yellow Peril Revisited, 10.

24 For example, 'Every case can be linked back to the original index case, a 78-yearold grandmother and immigrant from Hong Kong'. Seeman, 'Toronto Under SARS', 2. http://www.nationalreview.com/script/printpage.asp?ref=/comment/ comment-seeman042503 (accessed 1 July 2004). See also, 'How a deadly disease made its way to Canada', Toronto Globe and Mail (29 March 2003): A1, A15.

25 Basrur to Board of Health, 12.

26 Gilmore, Coming Soon, 64.

27 Helen Branswell, 'Chorus of outraged voices denounces WHO warning against travel to Toronto', Canadian Press Newswire, 25 April 2003, p. 3. See also 'Toronto angry over SARS warning' http://news.bbc.co.uk/1/hi/world/americas/2971217.stm (accessed 13 April 2006).

28 André Picard and Caroline Alphonso, 'Shock, Anger greets WHO advisory' Toronto Globe and Mail, 25 April: A1.

29 Kevin Ward, 'British editorial opinion split over Toronto's addition to SARS travel list', Canadian Press Newswire, 24 April 2003, p. 1. A Times of London editorial expressed the same assessment: "The situation [in Toronto] is not at all the same as in Beijing"' (quoted in ibid.).

30 'Beijing closes public places over SARS', http://www.cnn.com/2003/HEALTH/ 04/27/sars.wrap/index.html (accessed 1 July 2004).

31 T. Corcoran, 'SARS a test run for more power', National Post, 26 April 2004, p. 11.

32 'SARS according to Mayor Mel', Toronto Globe and Mail (26 April 2003): A8.

33 For a cross-aesthetic overview of the exotic's appeal, see D. Lach, Asia in the eyes of Europe: Sixteenth through Eighteenth Centuries (Chicago: The University of Chicago Library, 1991).

34 E. Hansen and B. Gordon, Exotic Destinations (San Francisco: Full Data Limited, 1994). 
35 The London-based Satiric Press lampooned the way that SARS publicity brought Toronto world recognition: 'Lastman believes that Toronto will be more respected by the international community now that it's made the WHO's list of most dangerous cities to visit'. http://www.satiricpress.com/sp/archive/ archive_articles_bysubject.asp\#canadianpolitics (accessed 1 July 2004).

36 G. Huggan, The Postcolonial Exotic: Marketing the Margins (London: Routledge, 2001). Huggan argues that post-colonial literature, as well as the academic field of post-colonial studies are both discourses of the exotic.

37 E. Fürsich and M. Robins, 'Africa.com: The Self-Representation of Sub-Saharan Nations on the World Wide Web', Critical Studies in Media Communication, 19 (2002): 198.

38 'Increasing Toronto's Profile Internationally and at Home (All Wards)', Report No. 10, Economic Development and Parks Committee, Toronto City Council Minutes, 26, 27, 28 November 2002, pp. 4, 5.

39 'Reviving Tourism in Toronto', Toronto City Summit Alliance, 'Enough Talk, an Action Plan for the Toronto Region, ' April 2003, p. 10. The latter study was conducted over the second half of 2002. It was presented to City Council in April 2003, at the peak of the first outbreak.

40 J. Willis and S.J. Page (ed.), Managing Tourist Health and Safety in the New Millennium (London: Pergamon, 2003).

41 'Increasing Toronto's Profile'.

42 T. Noah, 'The Canadian Menace: SARS, Toronto and Danger', Slate, 24 April 2003. http://slate.msn.com/id/2081979/ (accessed 13 April 2006).

43 'Fear hurts Toronto as much as SARS: mayor', http://www.cbc.ca/story/news/ national/2003/04/24/sars_toronto030424.html (accessed 13 April 2006). See also Jennifer Lewington, 'Lastman's Gaffes Hurt Toronto', Toronto Globe and Mail, (26 April 2003): A1.

44 'Remarks by Toronto Mayor Mel Lastman at a special meeting of Toronto City Council', 24 April 2003. www.city.toronto.on.ca/mel_lastman/speeches/sarsreponse_council_2003.htm (accessed 1 July 2004).

45 The words, 'You Belong Here' were scripted by one of the advertising designers, not printed in a professional font. Carolyn Strange interview with Duncan Ross, Executive Director, Tourism Toronto, Toronto, 5 October 2004. Ross commented: 'she happened to have nice handwriting'.

46 G. Galloway and W. Immen, 'Canadians get tough assignment: Love Toronto', Toronto Globe and Mail (29 April 2003): A1.

47 http://wx.toronto.ca/inter/it/newsrel.nsf/0/e7c57d31822c704085256 df60045c930?OpenDocument (accessed 13 April 2006).

48 'Hot, Sweaty SARSstock a Smash Hit', was the CBS news headline. http:// cbsnews.com/stories/2003/07/31/entertainment (accessed 1 July 2004). A Toronto cab driver offered his own media analysis: 'they beamed pictures of the concert around the world, and showed that hundreds of thousands of people can gather, without a SARS mask in the crowd, without any ill effects'. N. Van Rijn, 'City on the road to recovery', Toronto Star (2 August 2003): A1.

49 Canadian politicians had more authority but less panache: 'I think it's important we get the message out that Canada is safe', the Deputy Prime Minister stated in a post-concert interview.

50 Examples in this large literature include V. Prashad, 'Native Dirt/Imperial Ordure: The Cholera of 1832 and Morbid Resolutions of Modernity', Journal of Historical Sociology, 7 (1994): 243-60; W. Anderson, 'Excremental Colonialism: 
Public Health, and the Poetics of Pollution' in A. Bashford and C. Hooker (eds) Contagion: historical and cultural studies, (London: Routledge, 2001), pp. 76-105; D. Arnold, Colonizing the Body: State, Medicine and Epidemic Disease in NineteenthCentury India (Berkeley: University of California Press, 1993); M. Swanson, 'The Asiatic Menace: creating segregation in Durban, 1870-1900', International Journal of African Historical Studies, 16 (1983): 401-21; Bashford, Imperial Hygiene, 1-7.

51 Shah, Contagious Divides, 120.

52 D. Seguin, 'Hawking Hogtown: Toronto's Image Problem', Canadian Business, 76, no. 10 (26 May 2003): 112-17.

53 The project is a joint initiative of the City of Toronto, Tourism Toronto, the Ontario Ministry of Tourism and Recreation and the Toront03 Alliance. It was initially recommended by City Council in November 2002. See http://www.toronto.ca/branding/pdf/2002_Branding_StaffReport.pdf (accessed 13 April 2006).

54 The Branding Project received 4,500 submissions which 'really helped get a better picture of Toronto today, as well as an excellent idea of what the public wants the city to become'. The team also conducted focus groups in Canada, the US and the U.K. http://www.toronto.ca/unlimited/background.htm\#final (accessed 13 April 2006).

55 The 'quote of the month' for April 2004 on the Tourism Toronto website is: 'Diversity not only rules [in Toronto], it's celebrated with a vengeance'. Carla Waldemar, Lavendar Magazine: http://torontotourism.com/media (accessed 3 June 2004).

56 Anti-racist and labor groups consistently attempted to draw attention to the racist dimensions of the SARS crisis, and complained that cash infusions were directed to major businesses, rather than the most vulnerable workers. See, Toronto Labor Council, "SARS": Toronto responds to a major community crisis', http://www.labourcouncil.ca/sars.html (accessed 1 July 2004), and T. Goossen, C. Pay and A. Go, 'Healing the scars in post-SARS Toronto', Toronto Star (19 May 2003), http://www.buzzardpress.com/acla/sars/ healing_scars_post-sars.html (accessed 13 April 2006).

57 Hier and Greenberg, 'Constructing a Discursive Crisis', 508. 